\title{
MEF2B wt Allele
}

National Cancer Institute

\section{Source}

National Cancer Institute. MEF2B wt Allele. NCI Thesaurus. Code C92158.

Human MEF2B wild-type allele is located in the vicinity of 19p13.11 and is approximately $47 \mathrm{~kb}$ in length. This allele, which encodes myocyte-specific enhancer factor 2B protein, plays a role in the modulation of transcription. A translocation, $t(1 ; 19)(q 23 ; p 13.3)$ involving this gene and the DAZAP1 gene, creates reciprocal DAZAP1/MEF2D and MEF2D/DAZAP1 fusion genes that both are expressed in acute lymphoblastic leukemia. 